\title{
THE
}

\section{Preparing reading/literacy specialists to meet changes and challenges: International Literacy Association's Standards 2017}

Diane Kern

University of Rhode Island, dkern@uri.edu

Rita M. Bean

Allison Swan Dagen

Beverly DeVries

Autumn Dodge

Follow this and additional works at: https://digitalcommons.uri.edu/education_facpubs

\section{The University of Rhode Island Faculty have made this article openly available.} Please let us know how Open Access to this research benefits you.

This is a pre-publication author manuscript of the final, published article.

Terms of Use

This article is made available under the terms and conditions applicable towards Open Access Policy Articles, as set forth in our Terms of Use.

\section{Citation/Publisher Attribution}

Kern, D., Bean, R. M., Dagen, A. S., DeVries, B., Dodge, A., Goatley, V., Ippolito, J.H., Perkins, J. H., \& WalkerDalhouse, D. (2018). Preparing reading/literacy specialists to meet changes and challenges: International Literacy Association's Standards 2017. Literacy Research and Instruction, 57(3), 209-231, doi: 10.1080/ 19388071.2018.1453899

Available at: https://doi.org/10.1080/19388071.2018.1453899 


\section{Authors}

Diane Kern, Rita M. Bean, Allison Swan Dagen, Beverly DeVries, Autumn Dodge, Virginia Goatley, Jacy Ippolito, J. Helen Perkins, and Doris Walker-Dalhouse 
Preparing Reading/Literacy Specialists and 2017 Standards

Preparing Reading/Literacy Specialists to Meet Changes and Challenges: International Literacy Association's Standards 2017

Diane Kern, University of Rhode Island

Rita M. Bean, University of Pittsburg

Allison Swan Dagen, University of West Virginia

Beverly DeVries, Southern Nazarene University

Autumn Dodge, Lynchburg College

Virginia Goatley, University at Albany

Jacy Ippolito, Salem State University

J. Helen Perkins, University of Memphis

Doris Walker-Dalhouse, Marquette University

Contact: Dr. Diane Kern, 297 Pine Hill Road, Wakefield, RI 02879

dkern@uri.edu, (401) 742-2389

Submitted: November 17, 2017

Revised and resubmitted: January 31, 2018 
Preparing Reading/Literacy Specialists and 2017 Standards

Changing times require changes in what reading/literacy specialists are required to know and be able to do. The International Literacy Association (ILA) has been involved in developing standards for preparing reading professionals for several decades (Kern, 2011). Universities and colleges, states, and school districts use these standards for making decisions about program development, certification, and hiring practices for literacy professionals, including reading specialists, literacy coaches, and literacy program supervisors/coordinators.

In this article, we describe major changes that differentiate the Standards for the Preparation of Literacy Professionals 2017 (Standards 2017) (ILA, 2018) from earlier versions, focusing on standards for the role of the reading/literacy specialist. We then elaborate on the content of each of the 2017 Standards and discuss implications for those involved in designing programs for preparing reading/literacy specialists.

\section{Changes in Roles}

In this section, we discuss specific changes in roles and titles of the standards (IRA, 2010; ILA, 2018), which have implications for programs and states planning certification, endorsement or credential pathways for reading/literacy specialists, literacy coaches and literacy coordinator/supervisors.

\section{Separation of Reading/Literacy Specialist from Literacy Coach}

The titles of reading specialist, literacy coach, literacy coordinator are often used interchangeably in schools and districts. A goal of the 2017 Standards was to differentiate among each of these roles in ways that reflected the findings described in the ILA The Multiple Roles of School-Based Specialized Literacy Professionals Research Brief (ILA, 2015a) and Position Statement (ILA, 2015b). Current research as well as economic, political, and social conditions 
that affect schools and how they function informed ILA's decision to create a set of distinct standards for the three roles of specialized literacy professionals.

By separating the roles, we have "sharpened the terminology" as recommended by Galloway and Lesaux (2014, p. 524). Standard requirements for the reading/literacy specialist now focus on the primary role as instructional, while maintaining an emphasis on the need for professionals to be able to work collaboratively with other educators. Standards for literacy coaches place primary emphasis on working with teachers in schools; whereas, standards for literacy coordinators/supervisors emphasize districtwide leadership of literacy programs. Thus, preparation programs can now focus their development efforts more precisely on the role of the reading /literacy specialist or coach or coordinator/supervisor.

\section{Key Changes in Standards}

Standards 2017 titles remain the same for Standards, 1, 2, 3, and 6 (see Table 1). Changes were made in the titles of Standard 4 and Standard 5. Standard 7: Practicum/Clinical Experiences, developed specifically for the three roles of the specialized literacy professionals, is an entirely new standard in Standards 2017.

\section{Changes in the Content and Implications: Standard by Standard}

Universities and colleges have an enormous task in designing, implementing, and evaluating programs for preparing reading/literacy specialists. They must prepare candidates who have the advanced content and pedagogical knowledge, skills, and dispositions that enable them to work effectively with students, especially those experiencing difficulty with reading and writing. In addition, they must prepare candidates who can collaborate with teachers so that students are receiving appropriate classroom instruction. The Standards Revision Committee (SRC), in the development process, continued to ask itself, "What does it mean to be a 
reading/literacy specialist? What 'advanced 'skills, knowledge, and dispositions are essential, beyond those expected of the classroom teacher, and how can these be incorporated in a coherent program that is effective and doable?"

Below we describe the content of each of the seven 2017 Standards, highlighting the research and theory serving as a basis for each of the standards. We then discuss implications for reading/literacy specialist program revision, design, and evaluation.

\section{Standard 1. Foundational Knowledge}

One of the most significant changes in the standards is the shift from a narrower focus on reading and writing to a broader perspective that acknowledges that candidates are responsible for literacy instruction of students. Such a change results from findings that identify the interrelatedness of the various components of the language arts and the importance of an integrated approach to literacy instruction (Gavelek, Raphael, Biondo \& Wang, 2000; Graham \& Hebert, 2010; Lawrence \& Snow, 2011). We see this shift in the expectations of standards for preparing teachers (e.g., National Board) as well as standards for students (e.g., Common Core State Standards [NGA \& CCSSO, 2010]), and similar standards developed by states that call for a more integrated model of literacy instruction.

To develop the content for this Standard, the SRC grappled with how literacy would be defined. For example, literacy has been defined as the ability to read and write. Other researchers conceptualized literacy more broadly, even incorporating political and social dimensions (Gee, 1990; Moll, Amanti, Neff, \& Gonzalez, 1992). We described three components of literacy: reading (1.1), writing (1.2), and language (1.3) (see Table 1). Component 1.3 (language) addresses the structure of language, speaking, listening, viewing and visual representation. We also highlighted the importance of the connectedness between and 
Preparing Reading/Literacy Specialists and 2017 Standards

among the components of literacy. Candidates for reading/literacy specialist certification must develop an understanding of the major theories and conceptual foundations of literacy (e.g., Alvermann, Unrau, \& Ruddell, 2013; August \& Shanahan, 2006; Kamil, Pearson, Moje, \& Afflerbach, 2010; MacArthur, Graham, and Fitzgerald, 2016; McGill-Franzen \& Allington, 2010; National Early Literacy Panel, 2008; Shanahan \& Shanahan, 2008, Tracey \& Morrow, 2017).

The fourth component of Standard 1 (1.4) focuses on the importance of the historical and evidence based foundations related to the role of the reading/literacy specialist (Bean, 2015; Bean, Kern, Goatley, Ortlieb, Shettel, Calo,...Cassidy (2015); Galloway \& Lesaux, 2014; Quatroche, Bean, \& Hamilton, 2001). Those aspiring to become reading/literacy specialists must possess knowledge about the role and the ways this role has evolved through the years if they are to be effective in their positions.

\section{Implications}

First, given the broader emphasis on literacy, those who develop programs must make decisions about what major theories and concepts are important for candidates entering the program. Program designers will need to reexamine the nature of instruction and assignments, that is, what do candidates need to learn that demonstrate an understanding of the ways in which the components of literacy are connected and the evidence that supports literacy learning. Programs will most likely need to reorganize their coursework in ways that emphasize the ways in which key theories (e.g., Behaviorist, Cognitive, Social Constructivist) have influenced literacy instruction. A key is to synthesize what is important for candidates to know, or as Snow, Griffin, and Burns (2005) indicate, we must sift through the knowledge to identify what aspects of it are useable for developing a reflective, experienced practitioner. 
Preparing Reading/Literacy Specialists and 2017 Standards

Second, those who prepare specialized literacy professionals will need to think differently about how to develop programs that emphasize the key function of reading/literacy specialists, that is to prepare educators who work primarily with students experiencing difficulties with reading; at the same time, they will need to include experiences that develop candidate knowledge about the other components of literacy that will strengthen their ability to be successful in their role. The Four Lenses of Learning (i.e., language based, meaning centered, social, and human), as described by Botel and Paparo (2016), provide a useful theoretical framework for thinking about literacy processes for learning to read and for literacy and its impact on subject area learning.

Third, given the complexity of literacy, choices must be made about what topics or themes are essential in programs designed to prepare reading/literacy specialists. The list below, in Table 2, although not inclusive, identifies some of those critical topics and resources for program designers.

Finally, the shift from reading to literacy has implications for how the foundational knowledge of literacy specialists will be assessed so that the knowledge base of literacy is well represented. Those who develop tests (e.g., state departments, programs, and standardized test developers, such as Educational Testing Service) may need to revise their examinations to ensure literacy foundational knowledge is measured.

\section{Standard 2. Curriculum and Instruction}

Changes in the content of Standard 2 also reflect the shift from reading to literacy.

Further, candidates are expected to use or apply foundational knowledge to make decisions about literacy curriculum and instruction; such as, ability to design, critique, and adapt literacy curricula (2.1); select or design evidence-based approaches and practices that meet the needs of 
whole class and small groups of students (2.2); select, adapt, teach and evaluate supplemental and intervention approaches (2.3); and ability to collaborate with and coach peers in developing, implementing and evaluating literacy instruction and curriculum (2.4) (see Table 1).

Being aware of the various, interrelated components of literacy requires candidates to be able to design instruction in which listening, speaking, reading, and writing are integrated as a means of improving students' literacy learning (Graham \& Hebert, 2010; Raphael \& Hiebert, 2013; Ankrum, 2017; Pearson \& Hiebert, 2015). Important shifts in literacy instruction that should influence the content in preparation programs include: a focus on reading and writing to inform, persuade, and convey experiences; a focus on increasing text complexity; a focus on speaking and listening; a focus on text-based evidence for argumentation; and a focus on academic vocabulary and language (Fisher \& Frey, 2013).

The major role of most reading/literacy specialists is that of working with students who in some way exhibit a propensity for reading difficulties or have been identified as having such difficulties; therefore, candidates must understand the nature of supplemental and intervention approaches effective for improving the literacy skills of these learners. Whether reading/literacy specialists work in specific intervention programs such as Response to Intervention, have responsibilities for students receiving Title 1 support, or for differentiating instruction to address literacy needs of students in a school or classroom, they must be able to demonstrate the ability to design instructional approaches and use materials that meet students' literacy needs.

The implications below are focused on the important role that reading/literacy specialists have in working with learners experiencing difficulty with literacy, At the same time, we acknowledge that these professionals should also have a deep and broader understanding of 
Preparing Reading/Literacy Specialists and 2017 Standards

curriculum and instruction that enables them to support the work of the overall school literacy program.

\section{Implications}

First, given that students with reading difficulties exhibit different characteristics, and patterns of reading abilities, (Buly \& Valencia, 2002; McGill-Franzen \& Allington, 2010), instructional interventions will need to vary. This variability requires reading/literacy specialists to be able to identify profiles of readers and to have a deep understanding of the various intervention approaches.

Second, reading/literacy specialists must be able to target instruction to meet the needs of students with whom they work. According to Snow, Burns, and Griffin (1998), instructional approaches for students with difficulties may not differ dramatically from that for readers who learn to read more easily; however, students with reading difficulties need instruction that is more explicit, intense, and more supportive (Foorman \& Torgeson, 2001; Wharton-McDonald, 2011). Such instruction is critical when teaching not just the foundational skills, but the meaning-based aspects of literacy. There is evidence that, when learning to read, many students, and especially those who struggle, need explicit, systematic, phonological and phonics instruction (National Institute of Child Health and Human Development, 2000; Connor, Alberto, Compton, \& O'Connor, 2014), which requires reading/literacy specialists to understand how the structure of language (Moats, 2004) impacts instruction. In addition to having the ability to teach more explicitly, candidates need to be able to intensify instruction by increasing instructional time and providing effective small group instruction. Of great importance, is the need for specialized literacy professionals to develop lessons that provide the scaffolding and the appropriate level of challenge that engage learners. Such instruction should be engaging and 
Preparing Reading/Literacy Specialists and 2017 Standards

provide opportunities for student choice to enhance student motivation to read and write (Guthrie, 2008).

Finally, given the range of levels at which these reading/literacy specialists might work, that is, from preschool through high school, there is much they need to know about curriculum and instruction. Program designers would be wise to consider ways in which to modify their programs to provide for some candidate choice. In other words, there may be options in the program such as the following: candidates who choose to work at the preschool or primary levels might take an additional course related to emergent literacy and beginning reading while those who choose to work at the high school level might have the opportunity to select a course about disciplinary or adolescent literacy. Certainly, there will need to be a basic strand for all candidates so that they have a common and foundational understanding of instructional approaches, but the need for some program variability is suggested.

\section{Standard 3 Assessment and Evaluation}

The primary goal of Standard 3, Assessment and Evaluation, is to enable candidates to use a variety of assessment tools and practices to plan and evaluate effective literacy instruction. Candidates are expected to understand the technical attributes of assessment instruments and to administer these appropriately, (3.1), to be able to collaborate with colleagues in interpreting results and use those results for instructional planning (3.2), to assist their colleagues in administering and analyzing results (3.3), and to communicate results and serve as advocates for stakeholders (3.4). (see Table 1).

Reading/literacy specialists need to be both experienced and strategic in knowing how to analyze data patterns that document students' strengths and needs to optimize student learning (Afflerbach, 2011; Lipson, Chomsky-Higgins, Kanfer, 2011; Scanlon, 2010). Another key 
aspect of their role is to use results of these assessments to evaluate the effectiveness of instructional practices. Therefore, specialists must understand the value of assessments and draw on multiple forms of assessment data to inform literacy instruction (Afflerbach, 2016; Roskos \& Neuman, 2012; Torgeson \& Miller, 2009; Vogt, Echevarria, \& Short, 2010; Wixson \& Valencia, 2011). They should be able to administer assessments with knowledge of purpose, audience, strengths/limitation, bias, etc. of each assessment tool. Then, they must use the results of multiple assessment tools to systematically evaluate literacy instruction within and across individuals, classrooms, and schools.

As school-level leaders, reading/literacy specialists play a key role in analysis of assessment data that can inform professional learning experiences and school/district improvement initiatives (Bean \& Lillenstein, 2012). The range of responsibilities has increased over time and the 2017 standards reflect this evolving nature of leadership of reading/literacy specialists in the assessment process.

Within a time period when many stakeholders attempt to dictate policy requirements about assessment, the 2017 Standards emphasize the need for specialists to be advocates for students and teachers with multiple audiences (e.g., parents, administrators, community members). Specialized literacy professionals should understand the local, interpretive, and situational contexts in which assessment occurs and draw on that knowledge to systematically use assessment data, "to plan instruction, select specific strategies for a given context or content, evaluate students' responses to instruction/intervention, engage their learners in self-appraisal, and critically reflect on practice (International Literacy Association, 2018).

\section{Implications}


Preparing Reading/Literacy Specialists and 2017 Standards

First, preparation programs need to provide activities and learning experiences that ensure candidates know how to select and administer assessments, determine which assessments to use, collaborate with colleagues to interpret results, use data results for instructional decision making, and communicate their findings to relevant stakeholders.

Second, given the shift from a focus on reading to a broader focus on literacy, program designers will need to consider what assessment measures to include in their programs so that candidates have a better understanding of how to measure, for example, writing, or language development. Likewise, what measures are important for assessing the needs of students at the early levels of schools as well as for those at the high school level? Only a finite number of assessment measures can be introduced within a program, and therefore program designers might take into consideration whether they have included those that can serve as examples of the following categories of assessment tools: formal standardized measures, screening measures, diagnostic tools, and informal measures. They might also focus on helping candidates develop an understanding of how to evaluate assessment tools and their appropriateness for specific purposes.

Finally, and perhaps most importantly, evaluation and the use of data should be linked to decision-making about instruction. This recommendation requires that program designers highlight the connections between Standard 2 and Standard 3.

\section{Standard 4 Diversity and Equity}

Standard 4 has been expanded to include a focus on educational equity. To accomplish this, literacy professionals are challenged to demonstrate leadership and to work collaboratively with students, teachers, district and community personnel, and families in advocating for equity for diverse students to eliminate school-based practices and institutional structures that are 
inherently biased. The goal is to use what we know about diversity and equity to teach reading/literacy specialists how to create a more culturally responsive literacy curriculum, and to interact in more socially just, culturally competent ways with families from varied communities-urban, rural, and suburban--in which schools are located. Second, the changes reflect a broader and more inclusive definition of diversity. This broader definition of diversity acknowledges the many ways in which individuals differ. The four components of Standard 4 are: the need for candidates to have knowledge of the major foundational theories about diversity learners, equity, and culturally responsive instruction (4.1); ability to demonstrate an understanding of themselves and others as cultural beings through their interactions with others (4.2); ability to create and advocate for inclusive and affirming classroom and school environments (4.3); and advocate for equity with various stakeholders (4.4) (see Table 1).

Standard 4 builds on seminal research used in Standards 2010 and expands the literature review to include additional theories, pedagogies, and essential concepts of diversity and equity. For example, we revisited Gloria Ladson-Billings' investigation of the literacy instruction of eight teachers of African-American students, which provided the foundation for a culturally relevant theory of education (Ladson-Billings, 1994; Ladson-Billings, 1995). This research informed theory that rejects a deficit approach to thinking about culturally diverse students and reinforces a belief in their capacity to learn.

Moll and Gonzalez (1994) conducted seminal ethnographic research with Mexican American families in working class communities that led to the funds of knowledge theory. The theory recognizes the accumulated and cultural knowledge and skills that children acquire as they function in their individual home environment. The knowledge that children acquire from 
their respective home and communities were considered resources to be recognized, valued, and used to advance their learning.

Third space theory (Gutiérrez, 2008, Gutiérrez, Baquedano-Lopez, \& Tejeda, 1999) is based on seminal research conducted with migrant farmworker families that recognizes the home and community knowledge of students, and the activities and practices of schools. The theory supports a creation of a third space in which the different knowledge acquired by students from their home, school, and communities is brought together and used to create new teaching and learning opportunities.

\section{Implications}

First, faculty aligning their reading/literacy specialist curriculum and assessments to the 2017 Standards may want to examine their programs for inclusion of experiences that develop candidates' content knowledge, their own cultural competence, and ability to implement culturally responsive pedagogies and practices with students and their families. For example, candidates might be required to engage in personal assessment of their own attitudes and beliefs about diversity and to participate in professional development activities that enable them to understand theories across all forms of diversity. Another experience might include collaborating with other educators to analyze and set equitable goals for student learning that respect and affirm students' identities and recognize the funds of knowledge that they bring to learning.

Second, program faculty are encouraged to find ways to help candidates: reflect about the representation of diversity in the school curriculum, materials, and routines used in creating an inclusive environment for learning; to collaborate with families in support of students' learning and to seek opportunities to use the knowledge of students' home and school communities to 
connect their home and school literacies; and to advocate for policy, procedures, and curriculum that address issues of social justice, advocacy, activism, and resiliency.

Finally, reading/literacy specialist candidates would benefit from multiple opportunities to observe, plan, and teach diverse students in school settings. Candidates should engage in personal reflection that examines the extent to which they understand, affirm and validate students' diversity. Subsequent critical discussions of the academic needs of students across all forms of diversity could be discussed, along with the changes needed to improve instructional practices and learner outcomes. An outgrowth of the discussions might be the creation of a plan for advocacy that builds upon candidates' understanding of school and community demographics and assets, and recognizes the relevance of diversity to language learning, literacy development, motivation, engagement, and achievement.

\section{Standard 5 Learners and the Literacy Environment}

In 2017, the "learner" was added to emphasize the centrality of students in the literacy learning environment. Moreover, we expanded the notion of environment to address contextual factors influencing $21^{\text {st }}$ century learning, namely digital literacies. The four components include meeting the developmental needs of learners (5.1), access to and integration print, digital texts and online resources (5.2) safe and effective use of digital technologies (e.g., devices, texts, interactions, and tools) (5.3) and the ways reading/literacy specialists play an integral role in fostering a positive literacy learning environment (5.4) (see Table 1).

How the field unpacks the construct of environment, should both be in response to and directed toward the evolving needs of all learners, from those at risk to advanced learners and those with exceptionalities. In the past, for example, researchers have looked at environment's print rich influence on young learners (Wolfersberger, Reutzel, Sudweeks \& Fawson, 2004), 
Preparing Reading/Literacy Specialists and 2017 Standards

social interaction and play (Pellegrini \& Galda, 1993), and access to materials (Roskos \& Neuman, 2001) to define effective elements in creating physical and social spaces for learning. In revising this standard, we acknowledge and include this key research that focuses on both the physical and social aspects of environments including access, grouping, routines and classroom configuration.

There are two major additions to this body of existing research. First, is the acknowledgement of the centrality of the individual literacy learner in any consideration of the literacy environment. It is expected that reading/literacy specialists will have knowledge and understanding of theoretical models of learner development and learner differences. This also requires programs to provide opportunities for candidates to engage with learners of a wide range of age, abilities (e.g., English learners, gifted, those experiencing difficulty with literacy tasks), and development.

The second major revision of Standard 5 emphasizes the deictic nature of literacy (Leu, Kinzer, Coiro, Castek, Henry, 2013), which in the 21st century is driven by the speed in which technology evolves, changes, and influences schooling and society. Literacy learners are immersed in and engaged with social media, have 24/7 access to news and information, and use functional tools and applications daily. Standard 5 acknowledges that literacy learners live in a world of digital tools, devices, and interactions to communicate and learn. The treatment of digital literacies in Standard 5, and across the standards, is a response to what it means to be literate. Digital technologies are changing the definition of literacy); digital literacy simply is literacy (Castek, 2015). Leu states, "social contexts have always shaped both the function and form of literate practices and been shaped by them in return" (2013, p. 1151). In Standard 5, we address digital literacies as the multiple ways we read, write, communicate using digital 
technologies (e.g., tools and devices). The Standards acknowledge that digital literacies influence the way learners consume, create and communicate/share digital content (e.g., blogs, social media, You Tube). Further, digital (and print) texts provide nearly unlimited choices, and reading/literacy specialists need to recognize their role in personalizing the individual student literacy experience. Guiding students' use of new tools and providing feedback helps develop the skills needed to find and evaluate information, create representations of their learning, and share ideas in ways that extend student literacy learning

\section{Implications}

First, implications for programs preparing reading/literacy specialists include a call for increased in depth learning experiences to develop foundational knowledge about individual learners, digital technologies, digital literacies and learning environments. Program coordinators and faculty can use the ILA Standards 2017 (2018) as a framework to review existing coursework and program curriculum.

Programs might also consider reviewing their treatment of the "learner" throughout the entire program. Introducing various developmental theories, in an already packed program, may occur as part of a foundations course or through a partnership with Educational Psychology department. A second wave of program reflection may involve asking deeper questions, such as, what is the program's theoretical orientation and beliefs about development, engagement, motivation, and intervention specific to individual learners experiencing difficulties with reading and writing? Also, how does the program provide candidates with opportunities to apply this knowledge in field experiences, either in schools or within community settings?

Second, programs might consider reviewing their treatment of "digital literacies" throughout the entire program. For example, candidates will need to understand major theories 
and research findings related to these new literacies (Leu, Kinzer, Coiro, Castek, \& Henry, 2013), technology-enhanced learning principles, and students' out- of-school digitally supported literacy engagements. As well, programs need to ensure candidates learn how this information influences instructional practices. An additional level of review may look at how programs model their own use of print and digital materials and how they support candidate's own learning in the program.

Last, programs might consider reviewing their treatment of "literacy environments" throughout the program, In addition to the physical (e.g., what we see) and non-physical (e.g., how we feel) elements of environments, program might determine how they develop knowledge and application on bridging in and out of school literacy (Hull \& Schultz, 2001); engaging parent and community in literacy learning (Paratore, Cassano \& Schickendanz, 2010); recognizing how both physical, social and emotional learning contexts contribute to collaborative learning opportunities (Kriete, 2014; Snow, Burns \& Griffin, 1998), and recognizing learners' motivation and choice (Gambrell, 2011; Guthrie \& Wigfield, 2000). Another level of review may require programs to think about how they model and provide candidates opportunities for social interaction. What opportunities are presented throughout the program so candidates may collaborate on decisions impacting literacy learners (e.g., grouping patters and routines)?

\section{Standard 6: Professional Learning and Leadership.}

The 2017 Standards focus more clearly on candidates demonstrating the ability to: seek out and reflect on their own professional learning activities (6.1); engage in collaborative decision making with colleagues (6.2); demonstrate leadership and facilitation skills (6.3); and apply their knowledge when advocating for students, teachers, and the larger community (6.4) (see Table 1). 
Preparing Reading/Literacy Specialists and 2017 Standards

The separation of the reading/literacy specialist from the literacy coach role in the 2017 Standards required a new way of thinking about the expectations for Standard 6. Although their primary role is to teach students who are experiencing difficulties with literacy tasks, they must also be able to collaborate with and support colleagues in delivering effective literacy instruction. They should continue to be involved in the development of schoolwide literacy programming and may be involved in mentoring and coaching their peers. However, their primary role is to teach students who are experiencing difficulties with literacy tasks AND support colleagues in delivering effective instruction that meets student literacy needs.

The shifts in Standard 6 are modest but important and based on recent research and policy about professional learning and the roles of literacy professionals in schools (Bean \& Ippolito, 2016; Galloway \& Lesaux, 2014; Risko \& Vogt, 2016). Standard 6 encourages preparation programs to expand their focus on reading/literacy specialists as leaders and facilitators of both student and adult learning, facilitators who understand and know how to use discussion-based protocols and can lead collaborative decision-making (Breidenstein, Fahey, Glickman \& Hensley, 2012). Revised Standard 6 also encourages reading/literacy specialist candidates to model best practices with students and design/lead professional learning for colleagues that improves literacy instruction and intervention work. Finally, the 2017 version of Standard 6 increases the emphasis on advocacy, as reading/literacy specialists have the potential to play a vital role as literacy leaders within their schools and communities (Bean \& Ippolito, 2016).

\section{Implications}

First, preparation programs that prepare reading/literacy specialists must continue to provide learning opportunities that develop candidates' ability to be critical consumers of literacy research and promising practices in literacy instruction and assessments. Often, reading/literacy 
Preparing Reading/Literacy Specialists and 2017 Standards

specialists are involved in leading or facilitating team meetings (e.g., grade level, data teams, academic departments). Programs should make candidates aware of these leadership possibilities by providing experiences that develop candidates' understanding of how to lead and participate in collaborative discussions about instruction, how to facilitate decision-making, and how to support teacher learning in the school.

Second, candidates can be provided with opportunities to develop and lead advocacy efforts within the school and larger community. During fieldwork, candidates might collaborate with school-based specialists and coaches to organize and lead family literacy events that encourage all family members to engage in rich literacy activities (e.g., supporting parents in effectively choosing and reading texts with students at home) (Taylor, 1983).

Ultimately, the 2017 Standards position reading/literacy specialists increasingly as teacher leaders within their schools; consequently, preparation programs that have traditionally focused exclusively on preparing candidates to "teach literacy only" may increasingly need to collaborate with colleagues in education or organizational leadership preparation programs to borrow courses from principal preparation programs to better support candidates' knowledge and skills related to leading adult learning, facilitating professional conversations, and supporting school change. Course and fieldwork that attends both to effective literacy instruction and leading adult professional learning will ultimately serve future reading/literacy specialists quite well.

\section{Standard 7: Practicum/Clinical Experiences}

The 2017 Standards include a new standard designed to set clear expectations for programs designing practicum/clinical practices in university clinics, centers, and schools. Practicum experiences may occur in candidates' own classrooms and can be integrated 
Preparing Reading/Literacy Specialists and 2017 Standards

throughout the program and demonstrated through assignments such as assessing a specific student's literacy strengths and needs, lesson planning with a colleague, etc. The four components of Standard 7 are as follows: candidates demonstrate the ability to apply what they are learning by working with students in their own schools or in clinical settings (7.1) and to reflect on their teaching practices by working collaboratively with peers and experienced colleagues (7.2). Candidates are required to have one or more opportunities for authentic, schoolbased practicum experiences (7.3) and to receive supervision, from highly qualified supervisors (7.4) (see Table 1).

Standard 7 incorporates key aspects of the ILA (2015b) position statement on the Multiple Roles of Specialized Literacy Professionals states candidates should "engage with students experiencing difficulties with reading and writing, their families, and their teachers to extend candidates' experiences with appropriate planning, assessment, and instruction" and also have "various experiences related to adult learning and leadership" such as facilitating professional learning communities (pp. 14-15).

Lacina and Block's (2011) study examined programmatic features of six literacy teacher education programs that received the International Reading Association (IRA) Certificate of Distinction. Of the 14 highest ranking programmatic features, highest ranking was "consistent, carefully selected, and relevant field experiences" that were "closely tied...to content presented in courses" (Lacina \& Block, 2011, p. 336). In these programs of distinction, "each literacy related course contained field experiences" (p. 336). Further, faculty who taught the courses supervised field experiences and "immediate feedback was given by this supervisor as well as by fellow teacher candidates" (p. 336).

\section{Implications}


First, faculty must ensure candidates' practicum/clinical experiences are ongoing, allow for experiences that require candidates to work with students, especially those who struggle with literacy, occur in school settings, and provide opportunities for candidates to develop the ability to work collaboratively and reflectively. Development of ongoing experiences should allow for integration across coursework and program assessments.

Second, programs are encouraged to consider the use of technology in their practicum experiences, especially those that are supervised online. For example, video clips taken during intervention sessions with students can be used to inform reflection, critique, and plans for improvement. Likewise, those supervisors who cannot go into schools might consider using something similar to blue tooth technology to observe and provide feedback to candidates as they work with specific students (Rock, Gregg, Gable, \& Zigmond, 2009). The use of video clips might play heavily into how candidates receive feedback from supervisors and peers and engage in reflective practice. Standard 7 lays out guidance for using technology at all levels (e.g., observation, reflection, feedback, collaboration) to enhance literacy preparation programs of all formats (face-to-face, hybrid, and online). We suggest examining the work of those in the field using video reflection in literacy teacher education featured in the volume edited by Ortlieb, McVee, and Shanahan (2015), as well as Christ, Arya, and Chiu's (2012) work on the results of collaborative peer video analysis among literacy teachers.

Third, even though the primary role of the reading/literacy specialist is that of instruction, candidates do need experiences that provide opportunities to coach and or collaborate with peers. When working in a school or clinical setting, they might be able to "coach" each other as they discuss lesson plans and observe each other. It is also worthwhile for program developers to establish relationships with schools so that these candidates might be able to collaborate with 
Preparing Reading/Literacy Specialists and 2017 Standards

reading specialists in the field. In such an experience, the candidate and reading specialist can work collaboratively with teachers to make decisions about instructional approaches for students (Bean \& Ippolito, 2016). Candidates might also be able to take a leadership role in a professional learning community in the school in which they are working. This work could be integrated in a course where candidates learn about adult learning theories and professional development.

Finally, and of critical importance, those who lead, design, and teach in programs designed to prepare reading/literacy specialists need the skills, knowledge, and dispositions that enable them to provide the instruction and feedback that enable reading/literacy specialist candidates to become effective literacy professionals.

\section{Discussion}

The goals of this article were to provide a summary of key information about the 2017 ILA Standards for the Preparation of Literacy Professionals 2017 for the role of the reading/literacy specialist. Below we discuss several themes related to the 2017 Standards for preparing reading/literacy specialists: Designing a Reading/Literacy Specialist Program, Process for Program Re-design, and Supporting and Sharing Standards.

\section{Designing a Program}

Although we discussed implications for designing programs as they pertain to each standard, one cannot design a program without considering the overall standards to develop a coherent, comprehensive program that is doable, given the constraints of university programming. In other words, designers must think about ways to integrate learning experiences across standards and to design assessments that serve to measure several of the required components. For example, program designers might require candidates to assess a student and to design instruction that addresses the literacy needs of that student. In addition to addressing 
Preparing Reading/Literacy Specialists and 2017 Standards

components in Standard 2 and 3, the instruction might be assessed to determine whether it addresses issues related to Diversity and Equity (Standard 4) and to Student as Learner (Standard 5). Program designers are accustomed to this type of thinking, given their experiences with the 2010 Standards. However, it is even more critical at this time, given the greater demands of these standards.

The separation of reading/literacy specialist from literacy coach requires program designers to rethink the ways in which candidates are given opportunities to collaborate with and coach their peers. Currently many programs have a single course, often with titles such as Leadership Role of the Reading Specialist, or Coaching and Leadership. They may choose to keep such a course, or they may decide to embed coaching experiences and content within several courses. What our 2017 Standards acknowledge is that the single course in the previous programs was not sufficient for preparing those who became coaches in the schools. However, such courses are still extremely important first experiences for reading/literacy specialists who will need to know more about leadership, how to collaborate with their peers, and who may have some coaching responsibilities on-the-job. Given the emphasis on shared leadership as an important means of school improvement, such experiences also enable candidates to develop a better sense of their role as teacher-leaders, able to collaborate with others to improve overall literacy learning.

\section{Process for Program Design}

The process for new program design or re-designing an existing program can take many shapes. Meetings with colleagues at your own institution or in your region, especially if your program faculty is small, is a great way to start the process. Faculty could jigsaw the standards 1-7 to review the standard, components, and supporting research and literature. Then faculty could 
Preparing Reading/Literacy Specialists and 2017 Standards

meet in person or use distance communication technology, such as Skype or Zoom, to discuss. Faculty might also share their beliefs and philosophies about teaching reading, writing and language, acknowledging that each brings something important to the table. Below are a few guiding questions to foster robust conversations about key shifts in Standards 2017:

- Technology

- What digital literacy pedagogical knowledge and skills are required of reading/literacy specialists today?

- What technology supports, or professional development might the faculty need to teach digital literacy methods to our candidates?

- Diverse learners

- How does research delineate ways to foster candidates' cultural competence, dispositions and beliefs to best support students experiencing difficulties with reading and writing?

- We know that culturally-sustaining pedagogy builds upon the premises of culturally relevant instruction by "supporting young people in sustaining the cultural and linguistic competence of their communities while simultaneously offering access to dominant cultural competence (Paris, 2012, p. 95).” What might this look like in reading/literacy specialist Master's programs?

- Collaboration

- What do the research and literature on adult learning, peer collaboration and coaching suggest for those starting out in the role of reading/literacy specialist or other teacher-leader? 
Preparing Reading/Literacy Specialists and 2017 Standards

- How are recent graduates of our program(s) successfully collaborating or coaching in schools? What more do they wish they had learned while in our program?

- Advocacy

- What do successful experiences of family and community involvement in education look like and how do reading/literacy specialists strive to create bridges between in and out of school literacy experiences?

Another important step in the process of program re-design is to conduct a "gap analysis." In other words, analyze the 2017 Standards to determine the knowledge, skills and dispositions of candidates that were not included or emphasized enough in a program aligned to previous standards. The implications sections above may prove helpful as a starting point. Gaps discovered may include: shifting from reading to literacy foundational knowledge, curriculum, instruction and assessment; developing candidate dispositions on professional learning, collaboration and diversity; technology; and engaging candidates in advocacy.

\section{Supporting and Sharing Standards}

There are several sources of supports available to program designers and state policymakers to share ideas and expertise in implementing Standards 2017. The ILA website (https://www.literacyworldwide.org/get-resources/standards) has information on how to obtain various publications related to the Standards, FAQs, blog posts, Literacy Today articles, and additional resources. Attending sessions at conferences, including International Literacy Association (ILA), Association of Literacy Educators and Researchers (ALER) and Literacy Research Association (LRA), or joining specialty interest groups (SIGs) are great ways to learn from and with colleagues. 
Preparing Reading/Literacy Specialists and 2017 Standards

We also encourage those involved with the reading/literacy specialist programs to share their program's challenges and successes as well as their research on reading/literacy specialist teacher education. There is much need for continued research, both within and across institutions, to facilitate program improvement.

Last, tap into expertise within your own institution and education community! Resources from the Dean could help develop capacity for redesigning the program assessment system. For example, funds could be used to connect with ILA 2017 Standards experts to learn how to design performance based assessments and rubrics, and/or to visit reading/literacy specialist program faculty outside of your institution to share key assessments and ideas. Candidates also provide a valuable support to inform program improvement. Monitoring candidate data, using data to inform program improvements, program graduate surveys and focus groups with key partners, candidates, and recent graduates can also assist in learning more about the program and its excellence in achieving Standards 2017.

In sum, ILA 2017 Standards provide a national framework for rethinking programs for preparing reading/literacy specialists as well as a description of what is expected of those serving in the field. They necessitate a review of programs, that is a journey worth taking. Finally, while the standards are rigorous and require high expectations, they provide for flexibility in program design, implementation, and evaluation. 
Preparing Reading/Literacy Specialists and 2017 Standards

\section{References}

Afflerbach, P. (2011). Understanding and using reading assessment $K-12$ ( $2^{\text {nd }}$ ed.). Newark, DE: International Reading Association.

Afflerbach, P. (2016). Reading assessment: Looking ahead. The Reading Teacher, 69(4), 413419.

Alvermann, D. E., Unrau, N. J., \& Ruddell, R. B. (Eds.). (2013). Theoretical models and processes of reading (6th ed.). Newark, DE: International Reading Association.

Ankrum, J. (2017). Differentiated literacy instruction: Assessing, grouping, teaching. New York: Routledge.

August, D., \& Shanahan, T. (2006). Report of the National Literacy Panel on language minority children and youth. Philadelphia: Erlbaum.

Bean, R. M. (2015). The reading specialist: Leadership and coaching for the classroom, school and community ( $3^{\text {rd }}$ ed.) New York, NY: The Guilford Press.

Bean, R., Kern, D., Goatley, V., Ortlieb, E., Shettel, J., Calo, K., Marinak, B., Sturtevant, E., Elish-Piper, L., L'Allier, S., Lane, M., Frost, S., Mason, P., Quatroche, D., Cassidy, J. (2015). Specialized literacy professionals as literacy leaders: Results of a national survey. Literacy Research and Instruction, Taylor \& Francis, 1-32, DOI 10.1080/19388071.2014.998355.

Bean, R. M., \& Ippolito, J. (2016). Cultivating coaching mindsets: An action guide for literacy leaders. West Palm Beach, FL: Learning Sciences International. 
Preparing Reading/Literacy Specialists and 2017 Standards

Bean, R. M. \& Lillenstein, J. (2012), Response to intervention and the changing roles of schoolwide personnel. The Reading Teacher, 65(7), 491-501. doi: 10.1002/TRTR.01073

Botel, M. \& Paparo, L.B. (2016). The plainer truths of teaching, learning, and literacy. Ephrata, PA: Owl Publishing.

Breidenstein, A., Fahey, K., Glickman, C., \& Hensley, F. (2012). Leading for powerful learning: A guide for instructional leaders. New York: Teachers College Press.

Buly, M., \& Valencia, S. (2002). Below the bar: Profiles of students who fail state reading assessments. Educational Evaluation and Policy Analysis, 24(3), 219-239.

Castek, J. (2015). Instruction with multimodal, multiple texts. International Literacy Association E-ssentials Series: Newark, DE. http://reading.org/general/Publications/e-ssentials/e8064

Clay, M. (1966). Emergent reading behaviour. An unpublished doctoral dissertation. University of Auckland, New Zealand.

Christ, T., Arya, P., Chiu, M. M. (2012). Collaborative peer video analysis: Insights about literacy assessment and instruction. Journal of Literacy Research, 44(2), 171-199.

Connor, C.M., Alberto, P.A., Compton, D.L., O’Connor, R.E. (2014). Improving reading outcomes for students with or at risk for reading disabilities: A Synthesis of the contributions from the Institute of Education Sciences Research Centers (NCSER 20143000). Washington, DC: National Center for Special Education Research, Institute of Education Sciences, U.S. Department of Education. This report is available on the IES website at http://ies.ed.gov/.

Dobbs, C. L., Ippolito J., Charner-Laird, M. (2016). Layering intermediate and disciplinary literacy work: Lessons learned from a secondary social studies teacher team. Journal of Adolescent \& Adult Literacy, 60(2), 131-139. 
Preparing Reading/Literacy Specialists and 2017 Standards

Fisher, D. \& Frey, N. (2013). Common core English language arts in a PLC at work Grades 68. Bloomington, IN: Solution-tree Press.

Foorman, B.R., \& Torgeson, J. (2001). Critical elements of classroom and small-group instruction to promote reading success in all children. Learning Disabilities Research and Practice, 16(4), 203-212.

Galloway, E. P., \& Lesaux, N. K. (2014). Leader, teacher, diagnostician, colleague, and change agent. The Reading Teacher, 67(7), 517-526.

Gambrell, L. (2011). Seven rules of engagement: What's most important to know about motivation to read. The Reading Teacher, 65(3) 172-178.

Gavelek, J.R., Raphael, T.E., Biondo, S.M. \& Wang, D. (2000). Integrated literacy instruction. In M.L. Kamil, P.B. Mosenthal, P.D. Pearson, R. Barr. (Eds.). Handbook of reading research, Vol. III (pp. 587-608), New York: Erlbaum.

Gee, J. P. (1990). Social linguistics and literacies: Ideology in discourses. New York: Routledge. Graham, S., \& Hebert, M.A. (2010). Writing to read: Evidence for how writing can improve reading. A Carnegie corporation Time to act Report. Washington, DC: Alliance for Excellent Education.

Guthrie, J. T. (2008). Engaging adolescents in reading. Thousand Oaks, CA: Corwin Press. Guthrie, J.T., \& Wigfield, A. (2000). Engagement and motivation in reading. In M.L. Kamil, P.B. Mosenthal, P.D. Pearson, \& R. Barr (Eds.), Handbook of reading research: Volume III (pp. 403-422). New York: Erlbaum.

Gutiérrez, K. D. (2008). Developing a sociocritical literacy in the third space. Reading Research Quarterly, 43(2), 148-164. 
Preparing Reading/Literacy Specialists and 2017 Standards

Gutiérrez, K. D., Baquedano-Lopez, P., \& Tejeda, C. (1999). Rethinking diversity: Hybridity and hybrid language practices in the third space. Mind, Culture, and Activity, 6(4), 286303.

Holdaway, D. (1979). The foundations of literacy. Sydney, Australia. Ashton Scholastic.

Hill, J. D., \& Bjork, C. L. (2008). Classroom instruction that works with English language learners: Facilitator's guide. Alexandria, VA: Association of Supervision and Curriculum Development.

Hull, G. A., \& Schultz, K. (2001). Literacy and learning out of school: A review of theory and research. Review of Educational Research, 71(4), 575-611.

International Literacy Association (2010). Standards for reading professionals—Revised. Newark, DE: Author.

International Literacy Association (2015a). Multiple roles of specialized literacy professionals (Research brief). Newark, DE: Author. Retrieved from https://www.literacyworldwide.org/docs/default-source/where-we-stand/literacyprofessionals-research-brief.pdf?sfvrsn=ff3aa28e 10

International Literacy Association (2015b). Multiple roles of specialized literacy professionals (Position statement). Newark, DE: Author. Retrieved from https://www.literacyworldwide.org/docs/default-source/where-we-stand/literacyprofessionals-position-statement.pdf?sfvrsn=f33aa28e_4

International Literacy Association (2016). Dyslexia: Research advisory. Newark, DE: Author. Retrieved from_https://www.literacyworldwide.org/docs/default-source/where-westand/ila-dyslexia-research-advisory.pdf?sfvrsn=6 
Preparing Reading/Literacy Specialists and 2017 Standards

International Literacy Association. (2018). Standards for the preparation of literacy professionals 2017. Newark, DE: Author.

Kamil, M. L., Pearson, P. D., Moje, E. B., \& Afflerbach, P. P. (Eds.) (2010). Handbook of reading research, Vol. IV. New York: Routledge.

Kern, D. (2011). 62 years of the pendulum's swing: The role of the reading specialist. New England Reading Association Journal, 46(2), 67-72.

Kriete, R. (2014). The morning meeting book ( $3^{\text {rd }}$ edition). Greenfield, MA: Northeast Foundation for Children.

Ladson-Billings, G. (1994). The dreamkeepers: Successful teachers of African-American children. San Francisco, CA: Jossey-Bass.

Ladson-Billings, G. (1995). Toward a theory of culturally relevant pedagogy. American Educational Research Journal, 32(3), 465-491.

Lacina, J. \& Block, C. C. (2011). What matters most in distinguished literacy teacher education programs? Journal of Literacy Research, 43(4), 319-351.

Lawrence, J. \& Snow, C. (2011). Oral discourse and reading. In M.L. Kamil, P.D. Pearson, E. Moje \& P. Afflerbach (Eds.). Handbook of reading research, Vol IV (pp. 320-338), New York: Erlbaum.

Leu, D.J., Kinzer, C., Coiro, J., Castek, J., \& Henry, L.A. (2013). A dual level theory of the changing nature of literacy, instruction, and assessment. In N. Unrau and D. Alvermann (Eds.) Theoretical models and processes of reading (6th ed., pp.1150 - 1181). Newark, DE: International Reading Association.

Lipson, M. Y., Chomsky-Higgins, P., \& Kanfer, J. (2011). Diagnosis: The missing ingredient in RTI assessment. The Reading Teacher, 65(3), 204-208. 
Preparing Reading/Literacy Specialists and 2017 Standards

MacArthur, C. A., \& Graham, S., Fitzgerald, J. (Eds.) (2016). Handbook of writing research (2 ${ }^{\text {nd }}$ ed.). New York: Guilford Press.

McGill-Franzen, A. \& Allington, R.L. (Eds.) (2010). Handbook of reading disability research. New York: Routledge.

Moats, L. (2004). Teaching reading is rocket science: What expert teachers of reading should know and be able to do [Online]. Washington, DC: American Federation of Teachers. Retrieved November 11, 2017 from https://www.aft.org/sites/default/files/reading_rocketscience_2004.pdf

Moje, E. B. (2008), Foregrounding the disciplines in secondary literacy teaching and learning: A call for change. Journal of Adolescent and Adult Literacy, 52, 96-107. Retrieved from https://deepblue.lib.umich.edu/bitstream/handle/2027.42/88028/JAAL.52.2.1.pdf?sequence $=1 \&$ isAllowed $=\mathrm{y}$

Moll, L., Amanti, C., Neff, D., \& Gonzalez, N. (1992). Funds of knowledge for teaching: Using a qualitative approach to connect homes and classrooms. Theory Into Practice, 31(2), 132-141. Retrieved from http://www.jstor.org/stable/1476399

Moll, L. \& González. N. (1994). Lessons from research with language minority children. Journal of Reading Behavior, 26(4), 23-41.

National Early Literacy Panel. (2008). Developing early literacy: Report of the National Early Literacy Panel. Washington, DC: National Institute for Literacy.

National Governors Association Center for Best Practices (NGA) \& Council of Chief State School Officers (CCSSO) (2010). Common Core State Standards (English language arts). Washington, DC: Authors. 
Preparing Reading/Literacy Specialists and 2017 Standards

National Institute of Child Health and Human Development. (2000). Report of the National Reading Panel. Teaching children to read: An evidence-based assessment of the scientific research literature on reading and its implications for reading instruction (NIH Publication No. 00-4769). Washington, DC: U.S. Government Printing Office.

Neuman, S. \& Dickinson, D. (2001). Handbook for research in early literacy. New York: Guilford Press.

Ortlieb, E., McVee, M. B., \& Shanahan, L. E. (Eds.). (2015). Video reflection in literacy teacher education and development: Lessons from research and practice (Literacy research, practice and evaluation, Volume 5). Bingley, UK: Emerald Group Publishing Limited.

Paratore, J., and Cassano, C. \& Schickedanz, J. (2010). Supporting early and later literacy development at home and at school: The long view. In M. L, Kamil, P. D. Pearson, E. B. Moje \& P.P. Afflerback (Eds.) Handbook of reading research Vol. IV (pp. 107-135). New York: Routledge.

Paris, D. (2012). Culturally sustaining pedagogy: A needed change in stance, terminology, and practice. Educational Researcher, 41(3), 93-97.

Pearson, P.D., \& Hiebert. E. H. (2015). Research-based practices for teaching common core literacy. New York: Teachers College Press.

Pellegrini, A. D., \& Galda, L. (1993). Ten years after: A reexamination of symbolic play and literacy research. Reading Research Quarterly, 28(2), 162-175.

Perfetti, C. A. (2011). Reading processes and reading problems: Progress toward a universal reading science. In P. McCardle, J. Ren, O. Tzeng, \& B. Miller (Eds.), Dyslexia across languages: Orthography and the brain-gene-behavior link (pp. 18-32). Baltimore, MD: Brookes. 
Preparing Reading/Literacy Specialists and 2017 Standards

Piaget, J., \& Inhelder, B. (1969). The psychology of the child. New York: Basic Books.

Quatroche, D. J., Bean, R. M., \& Hamilton, R. L. (2001). The role of the reading specialist: A review of research. The Reading Teacher, 55(3). 282-294.

Raphael, T.E. \& Hiebert, E.H. (2013). Creating an integrated approach to literacy instruction. (Reading Essentials Reprint Series). Santa Cruz, CA: TextProject.

Risko, V. J., \& Vogt, M. (2016). Professional learning in action: An inquiry approach for teachers of literacy. New York: Teachers College Press.

Rock, M., Gregg, M., Gable, R., \& Zigmond, N. P. (2009). Virtual coaching for novice teachers: Technology enables university professors to observe and literally whisper in the ear of a teacher during instruction. Phi Delta Kappan, 36-41.

Roskos, K. A., \& Neuman, S. B. (2001). Environment and its influences for early literacy teaching and learning. In S. B. Neuman \& D.K. Dickinson (Eds.), Handbook of early literacy research (pp. 281-294). New York: Guilford Press.

Roskos, K. A., \& Neuman, S. B. (2012). Formative assessment: Simply, no additives. The Reading Teacher, 65(8), 534-538.

Scanlon, D.M. (2010). Response to intervention as an assessment approach. In A. McGillFranzen and R. L. Allington (Eds.), Handbook of reading disability research (pp. 139148). New York: Routledge.

Scarborough, H.S. (2001). Connecting early language and literacy to later reading (dis)abilities: Evidence, theory, and practice. In S. Neuman and D. Dickinson (Eds.), Handbook for research in early literacy (pp. 97-110). New York: Guilford Press.

Shanahan, T., \& Shanahan, C. (2008). Teaching disciplinary literacy to adolescents: Rethinking content-area literacy. Harvard Educational Review, 78(1), 40-59. 
Preparing Reading/Literacy Specialists and 2017 Standards

Shanahan, T., \& Shanahan, C. (2012). What is disciplinary literacy and why does it matter? Topics in Language Disorders, 32(1), 7-18.

Snow, C., Griffin, P., \& Burns, M.S. (2005). Knowledge to support the teaching of reading: Preparing teachers for a changing world. San Francisco, CA: Jossey-Bass.

Snow, C., Burns, M. S., \& Griffin, P. (Eds.). (1998). Preventing reading difficulties in young children. Washington DC: National Academy Press.

Snowling, M.G., \& Hulme, C. (2011). Evidence-based Interventions for reading and language difficulties: Creating a virtuous circle. British Journal of Educational Psychology, 81(Pt.1), 1-23.

Taylor, D. (1983). Family literacy. Exeter, NH. Heinemann Educational Books.

Torgeson, J. K., \& Miller, D. H. (2009). Assessments to guide adolescent literacy instruction. Portsmouth, NH: RMC Research Corporation, Center on Instruction.

Tracey, D. H., \& Morrow, L.M. (2017). Lenses on reading:. An introduction to theories and models $\left(3^{\text {rd }}\right.$ ed.). New York: Guilford Press.

Vogt, M.E., Echevarria, J., \& Short, D. (2010). The SIOP Model for teaching English language arts to English learners. Boston, MA: Pearson.

Wharton-McDonald, R. (2010). Expert classroom instruction for students with reading disabilities: Explicit, intense, targeted and flexible. In A. McGill-Franzen \& R. L. Allington (Eds.). Handbook of reading disability research (pp. 265-272). New York: Routledge.

Wixson, K.K., \& Valencia, S.W. (2011). Assessment in RTI: What teachers and specialists need to know. The Reading Teacher, 64(6), 466-469. 
Preparing Reading/Literacy Specialists and 2017 Standards

Wolfersberger, M., Reutzel, R., Sudweeks, R., \& Fawson, P. (2004). Developing and validating the classroom literacy environmental profile (CLEP): A tool for examining the "print richness" of early childhood and elementary classrooms. Journal of Literacy Research. $36(1), 83-144$.

Wood, C. (2007). Yardsticks: Children in classrooms ages 4-14 (3 $3^{\text {rd }}$ ed.). Center for Responsive Schools. Turners Falls: MA. 